\title{
ASAS-ASAS UMUM PEMERINTAHAN YANG BAIK YANG BERKEMBANG MELALUI PUTUSAN HAKIM
}

\author{
Tri Cahya Indra Permana \\ Universitas Muhammadiyah Tangerang, \\ Magister Hukum \\ Jalan Perintis Kemerdekaan I Babakan No.33, RT.007/RW.003, Cikokol, Kec. Tangerang, Kota Tangerang, Banten \\ 15118 \\ *tcindrapermana@gmail.com
}

\begin{abstract}
General principles of good governance developed by judge decision. Those general principles must be obeyed by government officials. Some of new principles made by judges among other things: principles of ultra petita, principles of prohibition of issued a decree who has been cancelled by the court, and principles of government fault can't disadvantage people. The aim of the developing general principles of good governance is to solve the administrative law problems.
\end{abstract}

KEYWORDS: General principles of good gonernance, Judge Decision

\section{INTRODUCTION}

Mahkamah Agung telah menyusun putusan-putusan yang menarik perhatian publik dan memiliki kaidah hukum baru yang disebut sebagai Landmark Decision, sedangkan Mahkamah Konstitusi menyebutnya sebagai Putusan Monumental.(Gautama, 1992; Nim, 2019) Putusan Pengadilan, baik yang berupa landmark decision ataupun putusan monumental yang berisi kaidah hukum baru dapat berupa pengembangan atas asas-asas umum pemerintahan yang baik yang sangat berguna bagi pengembangan hukum bukan hanya bagi para hakim selanjutnya, lebih jauh juga bagi para praktisi hukum, akademisi, mahasiswa serta bagi aparatur pemerintah dalam memperbaiki dan meningkatkan kualitas pelayanan publik kepada masyarakat.(Azhar, 2015; Sibuea, 2010)

Alat uji bagi Hakim Peratun dalam menjatuhkan Putusan adalah apakah keputusan dan/atau tindakan yang diterbitkan/dilakukan oleh Pejabat Tata Usaha Negara telah sesuai dengan peraturan perundang-undangan yang berlaku serta telah sesuai dengan asas-asas umum pemerintahan yang baik (AUPB) ataukah tidak.(Effendi, 2018) Khusus mengenai Asas-asas umum pemerintahan yang baik memiliki karakter yang khusus dalam hubungannya dengan hakim Peradilan Tata Usaha Negara dimana Hakim menjadikan AUPB sebagai alat uji (toetsing gronden) terhadap obyek sengketa, namun Hakim juga dapat menciptakan Asas yang baru dari AUPB.(Putri, 2014) 
Menurut Philipus Mandiri Hadjon, asas-asas umum pemerintahan yang baik (AUPB) harus dipandang sebagai norma-norma hukum tidak tertulis yang senantiasa harus ditaati oleh pemerintah. (Hadjon, 2011) Meskipun pengertian asas sesungguhnya adalah norma hukum tidak tertulis, namun Undang-Undang Nomor 30 Tahun 2014 tentang Administrasi Pemerintahan telah menyebutkannya didalam Pasal 10 sebagai berikut:

1. AUPB yang dimaksud dalam Undang-Undang ini meliputi asas:
a. Kepastian hukum
b. Kamanfaatan
c. Ketidakberpihakan
d. Kecermatan
e. Tidak menyalahgunakan kewenangan
f. Keterbukaan
g. Kepentingan umum, dan
h. Pelayanan yang baik

2. Asas-asas umum lainnya diluar AUPB sebagaimana dimaksud pada ayat (1) dapat diterapkan sepanjang dijadikan dasar penilaian hakim yang tertuang dalam putusan pengadilan yang berkekuatan hukum tetap.

SF Marbun menyebut Asas-asas Umum Pemerintahan yang Baik dengan Asas-asas Umum Penyelenggaran Pemerintah yang Layak (AAUPPL) karena dalam khasanah hukum administrasi Indonesia, kata berhoorlijk yang diterjemahkan kedalam Bahasa Indonesia dengan baik, layak atau patut, ternyata didalam penggunaannya masih banyak ditemukan ketidakseragaman. (Marbun, 2014)

Kuntjoro Purbopranoto sebagaimana dikutip oleh SF Marbun mengatakan bahwa perkembangan AAUPPL di Indonesia telah merangkum 11 (sebelas) asas yang berasal dari hukum administrasi belanda dan ditambahkan lagi 2 (dua) asas oleh Kuntjoro Purbopranoto yaitu sebagai berikut:(Marbun, 2014)

1) Asas kepastian hukum (principle of legal security)

2) Asas keseimbangan (principle of proportionality)

3) Asas kesamaan dalam mengambil keputusan (principle of equality)

4) Asas bertindak cermat (principle of carefulness)

5) Asas motivasi dalam setiap keputusan (principle of motivation)

6) Asas larangan mencampuradukkan kewenangan (principle of nonmisuse competence)

7) Asas permainan yang layak (principle of fair play)

8) Asas keadilan atau kewajaran (principle of reasonable or prohition of arbitrainess)

9) Asas menanggapi pengharapan yang wajar (principle of meeting raised expectation)

10) Asas meniadakan akibat keputusan yang batal (principle of undoing the consequences of unnulled decision)

11) Asas perlindungan atas pandangan (cara) hidup pribadi (principle of protecting the personal way of life)

12) Asas kebijaksanaan (principle of sapiently)

13) Asas penyelenggaraan kepentingan umum (principle of public service) 
Beberapa putusan di Peradilan Tata Usaha Negara yang meskipun tidak pernah disebut sebagai landmark decision, namun juga berisi asas-asas umum pemerintahan yang baik yang relatif baru dan belum termuat didalam Undang-Undang Administrasi Pemerintah maupun doktrin dan memiliki kaidah hukum baru guna menjawab problematika hukum dalam rangka pengembangan hukum administrasi. Adapun permasalahan yang akan dibahas adalah apakah telah ada asas-asas umum pemerintahan yang baik (AUPB) yang relatif baru yang berkembang melalui putusan peradilan tata usaha negara?

\section{METHODOLOGY}

Metode penelitian yang digunakan dalam penelitian ini adalah studi terhadap putusanputusan Pengadilan yang telah memiliki kekuatan hukum tetap maupun yang belum berkekuatan hukum tetap khususnya Putusan di lingkungan Peradilan Tata Usaha Negara untuk ditemukan kaidah-kaidah hukum yang terkait dengan asas-asas umum pemerintahan yang baik sebagai solusi atas permasalahan hukum administrasi.

\section{RESULTS AND DISCUSSION}

Berdasarkan putusan-putusan Peradilan Tata Usaha Negara yang telah berkekuatan hukum tetap yang diteliti telah terdapat beberapa asas-asas umum pemerintahan yang baik sebagai solusi atas permasalahan hukum antara lain sebagai berikut:

\section{Asas Ultra Petita dalam Putusan Partai Golkar}

Salah satu pertimbangan didalam Putusan No. 62/G/2015/PTUN.JKT tanggal 19 Mei 2015 adalah berbunyi sebagai berikut:

"Menimbang, bahwa guna menghindari kekosongan kepengurusan DPP Partai Golkar sebagai akibat ditunda dan dibatalkannya surat keputusan obyek sengketa oleh Pengadilan, pengadilan menegaskan bahwa DPP Partai Golkar hasil Munas Pekanbaru berdasarkan surat keputusan Menteri Hukum dan HAM RI No. M.HH-21.AH.11.01 Tahun 2012 tanggal 4 September 2012 tentang Pengesahan Susunan Komposisi dan Personalia masa bhakti 2009-2015 adalah berlaku selama penetapan nomor 62/G/2015/PTUN.JKT tanggal 1 April 2015 masih dinyatakan sah dan berlaku dan perkara ini belum berkekuatan hukum tetap. Hal demikian harus dilakukan oleh Pengadilan guna memberikan perlindungan hukum (rechtbescherming) bagi Partai Golkar untuk ikut serta mengikuti pilkada serentak dari kemungkinan berlanjutnya intervensi Menteri Hukum dan HAM dengan memanfaatkan proses upaya hukum (rechtmidellen) yang panjang dan konvensional berdasarkan hukum acara peradilan tata usaha negara. Sebagai organ lembaga negara yang diberi tugas dan kewenangan untuk menegakan hukum dan keadilan, Pengadilan tidak boleh membiarkan Tergugat yang nyata-nyata menggunakan hukum sebagai alat yang menyimpang dari tujuannya. Hak partai politik untuk mengikuti agenda politik nasional tidak boleh dirampas oleh Pejabat Tata Usaha Negara dengan berlindung pada asas praesumptio iustae causa".

Pertimbangan hukum tersebut dianggap ultra petita karena tidak ada tuntutan didalam gugatan mengenai siapa yang berhak mewakili partai Golkar untuk menandatangani kepengurusan pada saat pengurusnya sedang bersengketa. Namun dari pertimbangan hukum tersebut akhirnya telah muncul kaidah hukum baru yaitu: Hak Partai Politik untuk 
mengikuti agenda politik nasional tidak boleh dirampas oleh Pajabat TUN dengan berlindung pada asas praesumptio iustae causa terlepas dari siapapun pengurusnya, karena pada saat itu kepengurusan Partai Golkar Munas Bali tidak mendapatkan SK pengesahan dari Menkum HAM, sedangkan SK kepengurusan Munas Ancol ditunda pelaksanaannya dengan Penetapan Majelis Hakim (schorsing), maka kepengurusan Munas Pekanbaru yang masih berlaku saat itu dan tidak bersengketa dipandang layak mewakili Partai Golkar untuk menghindari kekosongan kekuasaan di tubuh Partai Golkar.

Namun demikian amar putusan di perkara tersebut tidak menyebutkan kepengurusan mana yang sah sehingga ultra petita hanya dimunculkan didalam pertimbangan tetapi tidak didalam amar putusan. Sesuai dengan kewenangannya dan didasari pada teori objectum litis, PTUN hanya boleh menguji apa yang menjadi obyek sengketa. Dengan demikian meskipun ultra petita pada prinsipnya dilarang, namun jika dilakukan demi keadilan untuk mencari solusi atas problem kenegaraan, maka hal tersebut diperbolehkan.

Norma hukum yang mengikuti dari pertimbangan hukum dalam putusan tersebut diatas yaitu Pasal 40A ayat (3), (4) dan (5) Undang-Undang Nomor 10 Tahun 2016 tentang Perubahan Kedua atas Undang-Undang Nomor 1 Tahun 2015 tentang Penetapan Peraturan Pemerintah Pengganti Undang-Undang Nomor 1 Tahun 2014 tentang Pemilihan Gubernur, Bupati dan Walikota Menjadi Undang-Undang yang menyebutkan:

a. Partai Politik yang dapat mendaftarkan pasangan calon sebagaimana dimaksud dalam Pasal 40 merupakan Partai Politik yang sah sesuai dengan ketentuan peraturan perundang-undangan.

b. Dalam hal terjadi perselisihan kepengurusan Partai Politik sebagaimana dimaksud pada ayat (1), kepengurusan Partai Politik tingkat pusat yang dapat mendaftarkan pasangan calon merupakan kepengurusan Partai Politik tingkat pusat yang sudah memperoleh putusan Mahkamah Partai atau sebutan lain dan didaftarkan serta ditetapkan dengan keputusan menteri yang menyelenggarakan urusan pemerintahan di bidang hukum dan hak asasi manusia.

c. Jika masih terdapat perselisihan atas putusan Mahkamah Partai atau sebutan lain sebagaimana dimaksud pada ayat (2), kepengurusan Partai Politik tingkat pusat yang dapat mendaftarkan pasangan calon merupakan kepengurusan yang sudah memperoleh putusan pengadilan yang telah memperoleh kekuatan hukum tetap dan didaftarkan serta ditetapkan dengan keputusan menteri yang menyelenggarakan urusan pemerintahan di bidang hukum dan hak asasi manusia.

d. Putusan Mahkamah Partai atau sebutan lain atau putusan pengadilan yang telah memperoleh kekuatan hukum tetap sebagaimana dimaksud pada ayat (2) dan/atau ayat (3) wajib didaftarkan ke kementerian yang menyelenggarakan urusan pemerintahan di bidang hukum dan hak asasi manusia paling lambat 30 (tiga puluh) hari kerja terhitung sejak terbentuknya kepengurusan yang baru dan wajib ditetapkan dengan keputusan menteri yang menyelenggarakan urusan pemerintahan di bidang hukum dan hak asasi manusia paling lambat 7 (tujuh) hari kerja terhitung sejak diterimanya persyaratan. 
e. Dalam hal pendaftaran dan penetapan kepengurusan partai politik sebagaimana dimaksud pada ayat (4) belum selesai, sementara batas waktu pendaftaran pasangan calon di KPU Propinsi atau KPU Kabupaten/Kota akan berakhir, kepengurusan partai politik yang berhak mendaftarkan pasangan calon adalah kepengurusan partai politik yang tercantum dalam keputusan terakhir Menteri yang menyelenggarakan urusan pemerintahan dibidang hukum dan hak asasi manusia.

\section{Asas Larangan Duplikasi Terhadap SK yang telah dibatalkan Pengadilan}

Dalam beberapa kasus, terdapat modus baru dari Pejabat terhukum yang memanfaatkan wewenangnya dengan menerbitkan Surat Keputusan baru yang sesungguhnya substansinya sama dengan Surat Keputusan yang telah menjadi obyek sengketa dan dinyatakan batal oleh putusan Pengadilan yang telah berkekuatan hukum tetap.

Modus tersebut bisa terjadi karena tiga hal. Pertama, agar tidak disebut sebagai Pejabat yang tidak patuh terhadap putusan Pengadilan, maka SK yang diwajibkan untuk dibatalkan dan dicabut telah dilaksanakan pembatalan dan pencabutannya, namun dibarengi dengan menerbitkan SK baru yang substansinya sama. Kedua, pada saat menerbitkan SK yang dibatalkan oleh Pengadilan sang Pejabat menerima suap atau gratifikasi sehingga berkepentingan untuk mempertahankan SK yang diterbitkannya dengan cara mengkloning SK. Ketiga, bisa juga karena sang Pejabat merasa yakin seyakin-yakinnya bahwa surat keputusan yang diterbitkannya sudah benar hanya putusan Pengadilan saja yang tidak memenuhi rasa keadilan bagi Tergugat atau lebih spesifik kurang mempertimbangkan dalildalil serta bukti Tergugat.

Terlepas dari kemungkinan alasan yang ketiga diatas, ada asas lain dalam hukum yaitu Res Judicata Pro Veritate Habetur yang kurang lebih bermakna putusan Pengadilan harus dianggap benar sampai dibatalkan oleh Putusan yang lebih tinggi. Jika dikaitkan dengan asas Praesumptio Iustae Causa, maka dengan adanya putusan Pengadilan yang berkekuatan hukum tetap yang membatalkan surat keputusan obyek sengketa, asas Praesumptio Iustae Causa menjadi terkalahkan karena tidak ada prinsip tanpa pengecualian. Atas dasar itu kloning terhadap suatu surat keputusan yang substansinya telah dibatalkan oleh Pengadilan dengan dalih putusan Pengadilan tidak memenuhi rasa keadilan Tergugat atau lebih spesifik kurang mempertimbangkan dalil-dalil serta bukti Tergugat rasanya kurang tepat.

Sebagai contoh dalam kasus tambang bijih besi di Pulau Bangka Minahasa Utara, Bupati Minahasa Utara telah melakukan kloning terhadap Izin Usaha Pertambangan yang telah dibatalkan oleh Pengadilan. Bahkan SK kloning tersebut dijadikan dasar oleh Perusahaan pemegang IUP untuk meningkatkan izinnya dari IUP menjadi IUP Operasi Produksi yang diterbitkan oleh Menteri ESDM. 
Masyarakat yang merasa dipermainkan, menggugat kembali SK IUP Operasi Produksi yang diterbitkan oleh Menteri ESDM tersebut dan sampai dengan putusan kasasi yang artinya telah mempunyai kekuatan hukum tetap, SK Menteri ESDM dinyatakan batal oleh Pengadilan. Putusan kasasi dalam perkara tersebut tertuang didalam Putusan Nomor 211/G/2014/PTUN.JKT jo Putusan Mahkamah Agung Nomor: 255 K/TUN/2016 tertanggal 11 Agustus 2016. Dalam putusan perkara Nomor 211/G/2014/PTUN.JKT terdapat pertimbangan hukum sebagai berikut:

Menimbang, bahwa berdasarkan bukti yang diajukan oleh para pihak, Majelis Hakim memperoleh fakta hukum bahwa Bupati Minahasa Utara telah 3 (tiga) kali menerbitkan IUP Eksplorasi atas nama Tergugat II-Intervensi yaitu :

a. Surat Keputusan Nomor 162 tanggal 20 Juli 2010 tentang Perpanjangan dan Perluasan Kuasa Pertambangan Eksplorasi serta penyesuaian menjadi Izin Usaha Pertambangan (IUP) Eksplorasi PT. Mikgro Metal Perdana (bukti P-3 selanjutnya disebut SK 162);

b. Surat Keputusan Bupati Minahasa Utara Nomor 152 Tahun 2012 tanggal 20 Juli 2012 tentang Perpanjangan Izin Usaha Pertambangan (IUP) Eksplorasi PT. Mikgro Metal Perdana di Pulau Bangka Kecamatan Likupang Timur Kabupaten Minahasa Utara (bukti P-5 selanjutnya disebut SK 152); dan

c. Surat Keputusan Bupati Minahasa Utara Nomor 183 Tahun 2012 tanggal 25 September 2012 tentang Perubahan Keputusan Bupati Minahasa Utara Nomor 152 Tahun 2012 tanggal 20 Juli 2012 tentang Perpanjangan Izin Usaha Pertambangan (IUP) Eksplorasi PT. Mikgro Metal Perdana di Pulau Bangka Kecamatan Likupang Timur Kabupaten Minahasa Utara (bukti P-7 = T.II.Int-7 selanjutnya disebut SK 183);

Menimbang, bahwa berdasarkan bukti P-8 berupa Putusan Mahkamah Agung RI Nomor 291 K/TUN/2013 tanggal 24 September 2013 diperoleh fakta hukum bahwa Surat Keputusan Bupati Minahasa Utara Nomor 162 tanggal 20 Juli 2010 tentang Perpanjangan dan Perluasan Kuasa Pertambangan Eksplorasi serta penyesuaian menjadi Izin Usaha Pertambangan (IUP) Eksplorasi PT. Mikgro Metal Perdana (bukti P-3), dan Surat Keputusan Bupati Minahasa Utara Nomor 152 Tahun 2012 tanggal 20 Juli 2012 tentang Perpanjangan Izin Usaha Pertambangan (IUP) Eksplorasi PT. Mikgro Metal Perdana di Pulau Bangka Kecamatan Likupang Timur Kabupaten Minahasa Utara (bukti P-5) tersebut telah dibatalkan oleh Putusan Pengadilan yang telah berkekuatan hukum tetap melalui Putusan Mahkamah Agung Nomor 291 K/TUN/2013 tanggal 24 September 2013 tersebut;

Menimbang, bahwa pada saat perkara tersebut masih berjalan dan belum mempunyai kekuatan hukum tetap, ternyata Bupati Minahasa Utara menerbitkan Surat Keputusan Bupati Minahasa Utara Nomor 183 Tahun 2012 tanggal 25 September 2012 tentang Perubahan Keputusan Bupati Minahasa Utara Nomor 152 Tahun 2012 tanggal 20 Juli 2012 tentang Perpanjangan Izin Usaha Pertambangan (IUP) Eksplorasi PT. Mikgro Metal Perdana di Pulau Bangka Kecamatan Likupang Timur Kabupaten Minahasa Utara (bukti P-7) dengan alasan diterbitkannya beberapa peraturan baru oleh pemerintah; 
Menimbang, bahwa setelah Majelis hakim mempelajari dan mencermati dengan seksama bukti P-7 tersebut, Majelis Hakim memperoleh fakta hukum sebagai berikut:

1) Didalam SK 183 tersebut tidak dijelaskan peraturan baru apa yang dimaksud oleh Bupati Minahasa Utara, bahkan didalam bagian mengingat tidak ada aturan yang secara spesifik dan signifikan mengharuskan dirubahnya SK 152;

2) Pada bagian memutuskan tidak ada hal yang berbeda antara SK 152 dan SK 183, justru keduanya sama persis;

Menimbang, bahwa oleh karena SK 183 substansinya sama dengan SK 162 dan SK 152 yang telah dibatalkan oleh Putusan Pengadilan yang telah berkekuatan hukum tetap, maka menurut pendapat Majelis Hakim, penerbitan SK 183 adalah tindakan yang tidak menghormati proses hukum oleh Bupati Minahasa Utara untuk mempertahankan surat keputusannya yang sedang diuji oleh Pengadilan;

Menimbang, bahwa hal tersebut pernah juga terjadi pada saat SK 162 masih menjadi obyek sengketa di Pengadilan dan belum mempunyai kekuatan hukum tetap, Bupati Minahasa Utara menerbitkan SK 152 yang substansinya juga sama dengan SK 162 (vide bukti P-6 berupa Putusan PT TUN Makassar Nomor 165/B.TUN/2012/PT.TUN.MKS tanggal 1 Maret 2013 halaman 26);

Menimbang, bahwa oleh karena SK 183 substansinya sama dengan SK 162 dan SK 152 yang telah dibatalkan oleh Pengadilan, maka menurut pendapat Mejelis Hakim tidak tepat untuk dijadikan sebagai dasar penerbitan obyek sengketa aquo;

Menimbang, bahwa yang menjadi keanehan justru Tergugat juga mendasarkan keputusannya pada Putusan Mahkamah Agung Nomor 291 K/TUN/2013 tanggal 24 September 2013, padahal Putusan Mahkamah Agung tersebut nyata-nyata telah membatalkan SK 162 dan SK 152 yang substansinya sama dengan SK 183;

Menimbang, bahwa atas dasar pertimbangan hukum tersebut, Majelis Hakim berpendapat bahwa demi adanya kesatuan hukum dan kepastian hukum, maka obyek sengketa aquo mengandung cacat yuridis dari segi substansi, dimana letak cacat yuridisnya telah dipertimbangkan secara lengkap didalam putusan PT TUN Makassar Nomor 165/B.TUN/2012/PT.TUN.MKS tanggal 1 Maret 2013 dan putusan Mahkamah Agung Nomor 291 K/TUN/2013 tanggal 24 September 2013;

Putusan Nomor 211/G/2014/PTUN.JKT jo Putusan Mahkamah Agung Nomor: 255 K/TUN/2016 tertanggal 11 Agustus 2016 tersebut diatas pada akhirnya mengabulkan gugatan Penggugat untuk seluruhnya dan menyatakan batal obyek sengketa serta mewajibkan kepada Tergugat untuk mencabut surat keputusan obyek sengketa. Dalam perjalanannya bahkan putusan yang telah berkekuatan hukum tetap tersebut telah dilaksanakan oleh Tergugat dalam hal ini Menteri Energi dan Sumber Daya Mineral RI melalui Keputusan Menteri Energi dan Sumber Daya Mineral Nomor 1361 K/30/MEM/2017 tanggal 23 Maret 2017 tentang Pencabutan Keputusan Menteri Energi dan Sumber Daya Mineral Nomor : 3109 K/30/MEM/2014 tanggal 17 Juli 2014 tentang Izin Usaha Pertambangan Operasi Produksi kepada PT. Mikgro Metal Perdana.

Gubernur Jawa Tengah juga menerbitkan SK yang pernah dijadikan sebagai obyek sengketa di Pengadilan Tata Usaha Negara Semarang dalam kasus izin lingkungan pendirian 
pabrik semen. Patut kiranya diteliti, mengapa Pejabat terhukum/Tergugat dalam hal ini Gubernur Jawa Tengah menerbitkan kembali SK izin lingkungan ? apakah SK kedua yang diterbitkan tersebut merupakan kloning dari SK pertama yang substansinya telah dibatalkan oleh Pengadilan dengan hanya berganti nomor dan tanggal SK ? atau memang SK yang diterbitkan kembali oleh Pejabat terhukum memang betul-betul memperbaiki SK yang telah dibatalkan Pengadilan sebagai pelaksanaan dari putusan Pengadilan berkekuatan hukum tetap yang dapat mengakhiri dahaga pencari keadilan ? Pertanyaan-pertanyaan tersebut patut untuk diajukan karena mengandung konsekuensi hukum yang berbeda untuk ditanggapinya.

Kloning terhadap SK yang sudah dibatalkan oleh Pengadilan dengan maksud sematamata mempertahankan SK merupakan pembangkangan terhadap hukum karena putusan Pengadilan adalah hukum yang juga harus dipatuhi. Berbeda konsekuensinya jika SK yang diterbitkan adalah pelaksanaan dari putusan atau corrective decision yang dapat mengakhiri dahaga pencari keadilan.

Undang-Undang administrasi Pemerintahan yang merupakan pedoman bagi Pejabat dalam bertindak belum mengatur adanya larangan kloning (duplikasi) terhadap SK yang substansinya telah dibatalkan oleh Pengadilan. Oleh karenanya Presiden sebagai pemegang puncak pemerintahan perlu untuk merespon fenomena yang sangat tidak diharapkan menjadi trend. Jika sikap Pejabat yang demikian dibiarkan tentu akan sangat mencederai rasa keadilan masyarakat dan kekhawatiran akan ditiru oleh Pejabat terhukum lainnya. Akibatnya orang berperkara tidak akan pernah selesai, karena setelah menang pun, SK baru akan diterbitkan kembali yang substansinya sama dengan SK yang telah dibatalkan oleh Pengadilan.

Peran Pengadilan juga ada yaitu jika menghadapi gugatan terhadap SK hasil kloningan maka Pengadilan berkewajiban membentuk atau melahirkan asas-asas umum pemerintahan yang baik melalui putusan yaitu asas larangan duplikasi terhadap SK yang telah dibatalkan oleh Pengadilan. Pengadilan dalam hal ini Pengadilan Tata Usaha Negara adalah forum yang tepat untuk membuktikan apakah SK yang diterbitkan kembali oleh Pejabat terhukum adalah SK kloningan/duplikasi atau justru sebaliknya SK yang dapat mengakhiri dahaga para pencari keadilan.

\section{Asas Kesalahan Pemerintah Tidak Boleh Merugikan Anggota Masyarakat}

Dalam Perkara Nomor 147/G/2015/PTUN.JKT Penggugat semula adalah Pegawai Negeri Sipil pada bagian Tata Usaha. Pada saat usianya sudah lebih dari 51 (lima puluh satu) Tahun, Penggugat diangkat menjadi seorang guru sehingga usia pensiunnya bertambah dari yang sebelumnya 56 (lima puluh enam) menjadi 60 (enam puluh) tahun. Ketika Penggugat memasuki usia pensiun karena telah berusia 60 (enam puluh) Tahun, Penggugat mendapati SK pensiunnya diberlakukan surut yaitu berlaku pensiun sejak Penggugat berusia 56 (lima puluh enam) tahun dan Penggugat diwajibkan untuk mengembalikan gaji yang diterimanya selama 4 (empat) tahun atau sekitar Rp. 200.000.000,- (dua ratus juta rupiah). SK pensiun yang berlaku surut tersebut kemudian dijadikan sebagai obyek sengketa di PTUN Jakarta. 
Dalam perkara tersebut didapati pertimbangan hukum dari Majelis Hakim sebagai berikut:

"Apabila pengangkatan, pemberhentian sementara dan pemberhentian PNS dari jabatan fungsional yang dilakukan oleh Pejabat Pembina Kepegawaian tidak sesuai dengan peraturan perundang-undangan yang berlaku dan mengakibatkan kerugian negara serta bukan karena kesalahan PNS yang bersangkutan, maka Pejabat Pembina Kepegawaian bertanggung jawab untuk mengembalikan kerugian keuangan negara tersebut kepada kas negara".

Hal tersebut bermakna bahwa Pejabat Pembina Kepegawaian harus berhati-hati dan bertanggung jawab atas Surat Keputusannya yang berpotensi menimbulkan kerugian keuangan negara. Namun apabila hal tersebut terjadi bukan karena kesalahan PNS yang bersangkutan, maka kerugian keuangan negara tersebut tidak boleh dibebankan dan merugikan PNS yang bersangkutan.

Untuk kasus Penggugat, berdasarkan bukti-bukti yang diajukan para pihak tidak ada unsur kesalahan yang dilakukan oleh Penggugat dalam pengangkatannya menjadi Guru di saat usianya sudah menginjak 51 (lima puluh satu) tahun 2 (dua) bulan dan 9 (sembilan) hari, sehingga berdasarkan asas kesalahan pemerintah tidak boleh dibebankan kepada anggota masyarakat seharusnya Penggugat tidak boleh dirugikan dengan diberlakukan surut (retroaktif) surat keputusan pensiunnya, namun seharusnya Penggugat tetap dipensiunkan pada usia 60 (enam puluh) tahun sesuai Pasal 30 ayat (4) Undang-Undang Guru dan Dosen.

Apabila kemudian keputusan pensiun Penggugat pada usia 60 (enam puluh) tahun tersebut akan menimbulkan kerugian keuangan negara, maka haruslah dibebankan kepada Pejabat Pembina Kepegawaian yang bersangkutan. Dengan demikian tindakan Tergugat menerbitkan surat keputusan obyek sengketa telah melanggar asas kesalahan pemerintah tidak boleh dibebankan kepada anggota masyarakat dari asas-asas umum pemerintahan yang baik.

Selanjutnya dalam amar putusannya Majelis Hakim PTUN Jakarta telah menjatuhkan putusan dengan amar sebagai berikut:

\section{DALAM PENUNDAAN}

\section{$\underline{\text { M E N G A D I L I }}$}

- Menolak permohonan penundaan pelaksanaan obyek sengketa yang dimohonkan oleh Penggugat;

\section{DALAM EKSEPSI}

- Menyatakan eksepsi Tergugat tidak diterima untuk seluruhnya;

\section{DALAM POKOK SENGKETA}

a. Mengabulkan gugatan Penggugat untuk seluruhnya;

b. Menyatakan batal Surat Keputusan Kepala Kantor Regional V Badan Kepegawaian Negara Nomor : 01664/KEP/FT/23100/14 tanggal 8 Desember 2014 tentang 
Pemberhentian Dengan Hormat sebagai Pegawai Negeri Sipil dengan hak pensiun atas nama Utam Rustam/NIP: 195506061978031009;

c. Mewajibkan kepada Tergugat untuk mencabut Surat Keputusan Kepala Kantor Regional V Badan Kepegawaian Negara Nomor: 01664/KEP/FT/23100/14 tanggal 8 Desember 2014 tentang Pemberhentian Dengan Hormat sebagai Pegawai Negeri Sipil dengan hak pensiun atas nama Utam Rustam/NIP: 195506061978031009;

d. Mewajibkan kepada Tergugat untuk memulihkan harkat dan martabat Penggugat dengan menerbitkan Surat Keputusan pensiun baru dalam jabatan Penggugat sebagai Pegawai Negeri Sipil dengan status tenaga Fungsional Guru terhitung mulai tanggal 1 Juli 2015;

Menghukum Tergugat untuk membayar biaya perkara sebesar Rp. 205.500,- (dua ratus lima ribu lima ratus rupiah) dan putusan PTUN Jakarta tersebut dikuatkan oleh Putusan Pengadilan Tinggi Tata Usaha Negara Jakarta Nomor 26/B/2016/PT.TUN.JKT tanggal 13 April 2016. Selanjutnya Tergugat/Pembanding mengajukan kasasi namun permohonan kasasi diajukan melebihi tenggang waktu 14 (empat belas) hari sesudah putusan diberitahukan sesuai Pasal 46 ayat (1) Undang-Undang Nomor 14 Tahun 1985 tentang Mahkamah Agung sehingga permohonan kasasi Tergugat/Pemohon Kasasi dinyatakan tidak memenuhi syarat formal oleh karenanya putusan Pengadilan Tinggi TUN Jakarta tersebut diatas telah berkekuatan hukum tetap.

Pada saat itu ditahun 2016 Putusan Pengadilan yang telah berkekuatan hukum tetap tersebut telah dilaksanakan oleh Tergugat dengan demikian Penggugat dapat memasuki masa pensiun dengan tenang.

\section{Asas Pengharapan Yang Wajar}

Asas pengharapan yang wajar sudah mulai dikembangkan dalam beberapa putusan di lingkungan Peradilan Tata Usaha Negara. Dalam perkara polemik pengangkatan Sekretaris Daerah Kota Bandung, Majelis Hakim PTUN Bandung menggunakan asas ini sebagai asas yang utama didalam pertimbangannya yang kemudian pada akhirnya mengabulkan gugatan Penggugat untuk seluruhnya.

Didalam putusan Nomor 58/G/2019/PTUN.BDG tanggal 1 Oktober 2019 tersebut, asas pengharapan yang wajar didefinisikan sebagai asas yang menghendaki agar setiap tindakan yang dilakukan pemerintah harus menimbulkan harapan-harapan. Jika harapan sudah terlanjur diberikan tidak boleh ditarik kembali meskipun tidak menguntungkan bagi pemerintah.

Wajar jika Penggugat berharap ia yang diangkat sebagai Sekretaris Daerah Kota Bandung karena pada dirinya tidak ada keadaan untuk tidak ditetapkan sebagai Sekretaris Daerah, antara lain: meninggal dunia, cacat permanen, ditahan oleh pihak berwajib atau ditemukan kemudian adanya cacat moral yang sebelumnya belum diketahui. 


\section{CONCLUSION}

Dari beberapa praktek peradilan seperti tersebut diatas, diperoleh beberapa kaidah hukum baru sebagai pengembangan dari asas-asas umum pemerintahan yang baik (AUPB) yang belum ada sebelumnya baik dari peraturan perundang-undangan yang berlaku maupun dari beberapa doktrin. Asas-asas umum pemerintahan yang baik yang relatif baru tersebut antara lain: asas ultra petita, asas larangan duplikasi terhadap surat keputusan yang substansinya telah dibatalkan pengadilan, asas kesalahan pemerintah tidak boleh merugikan anggota masyarakat, dan asas pengharapan yang wajar.

Atas kesimpulan tersebut, disarankan kepada para Pejabat Tata Usaha Negara agar didalam menjalankan pemerintahan memperhatikan dan mematuhi asas-asas umum pemerintahan yang baik. Sedangkan kepada jajaran Peradilan Tata Usaha Negara diberi saran agar teruslah menggali nilai-nilai hukum yang hidup dalam masyarakat dan menemukan hukum yang tidak tertulis dalam bentuk asas-asas umum pemerintahan yang baik yang baru sebagai solusi atas permasalahan bangsa.

\section{Referencces}

Azhar, M. (2015). Relevansi asas-asas umum pemerintahan yang baik dalam Sistem penyelenggaraan administrasi Negara. NOTARIUS, 8(2), 274-286.

Effendi, M. (2018). Peradilan Tata Usaha Negara Indonesia Suatu Pemikiran Ke Arah Perluasan Kompetensi Pasca Amandemen Kedua Undang-Undang Peradilan Tata Usaha Negara. Jurnal Hukum Dan Peradilan, 3(1), 25-36.

Gautama, S. (1992). Himpunan jurisprudensi Indonesia yang penting untuk praktek seharihari (landmark decision), berikut komentar (Vol. 1). Citra Aditya Bakti.

Hadjon, P. M. (2011). Pengantar hukum administrasi Indonesia. Gadjah Mada University Press.

Marbun, S. F. (2014). Asas-asas umum pemerintahan yang layak. FH UII Press.

Nim, O. Y. (2019). Kajian Yuridis Terhadap Eksistensi Mahkamah Konstitusi Dalam Menjalankan Fungsinya Sebagai Pengawal Konstitusi. Jurnal Fatwa Hukum, 2(4).

Putri, C. W. (2014). Asas Kepastian Hukum Dan Asas Kecermatan Sebagai Alat Uji Hakim Memutus Sengketa Tata Usaha Negara (Studi Kasus Putusan Nomor 19/G/2011 dan Putusan Nomor 24/G/2012 di Pengadilan Tata Usaha Negara Semarang) [PhD Thesis]. Diponegoro University.

Sibuea, H. P. (2010). Asas negara hukum, peraturan kebijakan, dan asas-asas umum pemerintahan yang baik. Jakarta: Erlangga.

Undang-Undang Nomor 5 Tahun 1986 tentang Peradilan Tata Usaha Negara beserta perubahan-perubahannya 
Undang-Undang Nomor 30 Tahun 2014 tentang Administrasi Pemerintahan

Undang-Undang Nomor 10 Tahun 2016 tentang Perubahan Kedua atas Undang-Undang Nomor 1 Tahun 2015 tentang Penetapan Peraturan Pemerintah Pengganti UndangUndang Nomor 1 Tahun 2014 tentang Pemilihan Gubernur, Bupati dan Walikota Menjadi Undang-Undang

Putusan Pengadilan Tata Usaha Negara Jakarta No. 62/G/2015/PTUN.JKT Tanggal 19 Mei 2015

Putusan Pengadilan Tata Usaha Negara Jakarta Nomor 147/G/2015/PTUN.JKT Tanggal 29 Oktober 2015

Putusan Pengadilan Tinggi Tata Usaha Negara Jakarta Nomor 26/B/2016/PT.TUN.JKT tanggal 13 April 2016

Putusan Pengadilan Tata Usaha Negara Jakarta Nomor 211/G/2014/PTUN.JKT tanggal 14 Juli 2015

Putusan Pengadilan Tinggi Tata Usaha Negara Nomor 271/B/2015/PT.TUN.JKT tanggal 14 Desember 2015

Putusan Mahkamah Agung Nomor : 255 K/TUN/2016 tertanggal 11 Agustus 2016

Putusan Pengadilan Tata Usaha Negara Bandung Nomor 58/G/2019/PTUN.BDG tanggal 1 Oktober 2019 